\title{
Red cell volume and red cell survival in normal aged people
}

\author{
A. D. F. HURDLE' AND A. J. ROSIN ${ }^{2}$ \\ From the Department of Pathology, West Middlesex Hospital
}

SYNOPSIS Estimations of red cell and blood volumes using ${ }^{51} \mathrm{Cr}$ were carried out on a group of 37 people over the age of 70 who were not anaemic. Subjects with clinical conditions known to affect red cell production were excluded. The mean values for red cell and blood volumes were found to be comparable with those of a control group of young adults. Seven people had red cell volumes below the accepted range in young adults but no reason was found for this difference.

Red cell survival was determined concurrently on 11 of the group and did not differ from those of young controls.

The question of whether the red cell volume in elderly people differs from that in young people is unsettled. The blood volume, expressed in terms of body weight, in men and women over the age of 60 was shown by Smith (1958) to be comparable with that of younger subjects. On the other hand, Reeve, Oddie, Bowman, and Rundle (1959) concluded that the blood and red cell volumes of a group of men over the age of 55 were significantly lower than in young adults.

The present investigation was designed to study red cell volume in elderly men and women with a normal haemoglobin concentration $(\mathrm{Hb})$ and normal haematocrit value (P.C.V.). Red cell survival studies were performed concurrently in 11 of the group in order to see whether advanced age is associated with a shorter corpuscular life span, as found by Takaku (1959), or whether the survival time is prolonged, as suggested by Casassa, Cerrato, and Turco (1957).

\section{INVESTIGATION}

SUBJECTS A group of 27 women and 10 men was studied, whose ages ranged from 70 to 90 years. Sixteen women and seven men were between 70 and 80 years, and 11 women and three men were over 80 . They comprised 14 in-patients of the geriatric department, and three from the orthopaedic department of the West Middlesex Hospital, three long-stay patients in a mental hospital, six residents of a county council welfare home, and 11 active people, who were working or were members of old folks' clubs. The hospital patients were chiefly

\footnotetext{
'Now at The Postgraduate Medical School, Ducane Road, W.12. ${ }^{2}$ Now at St. Pancras Hospital, N.W.1.

Received for publication 21 February 1962.
}

recovering from hemiplegia, and three were convalescing at least six weeks after a fracture. No subject was accepted unless the following criteria applied: No clinical evidence of infection; absence of oedema; no history of anaemia; $\mathrm{Hb}$ of $13.3 \mathrm{~g}$. per $100 \mathrm{ml}$. or more in men and $12.6 \mathrm{~g}$. per $100 \mathrm{ml}$. or more in women; P.C.V. of $40 \%$ or more. Each person was weighed. It was found difficult to measure the height accurately as many of the patients were kyphotic.

A group of healthy adults, six men and six women aged between 18 and 35 years, acted as controls for red cell volume estimations. The red cell survival of the six male controls was also measured.

METHODS Red cell survival was estimated using ${ }^{51} \mathrm{Cr}$. The patient's own red cells were labelled by the method of Mollison and Veall (1955) and injected intravenously. At least 12 blood samples were taken at intervals during the succeeding four weeks and the P.C.V. was determined on each. The radioactivity of the samples, haemolysed with saponin, was measured using a well-type scintillation counter. The rate of decay of radioactivity, in relation to the P.C.V., was estimated and the time of $50 \%$ decay $\left(\mathrm{T} \frac{1}{2} \mathrm{Cr}\right)$ was noted.

Twenty minutes after injection of the labelled cells, blood was taken for the determination of red cell volume. The venous haematocrit was corrected for trapped plasma, and further corrected to obtain the true body haematocrit, as described by Chaplin and Mollison (1952). Duplicate estimations were made in several cases and good agreement obtained between the results.

\section{RESULTS}

It was not possible to correct the subjects' weight for obesity by making use of published figures for weight with age, sex, and height, as described by 
TABLE I

RED CELL VOLUMES IN ELDERLY MALE AND FEMALE SUBJECTS AND IN YOUNG CONTROLS

\begin{tabular}{|c|c|c|}
\hline \multirow{2}{*}{$\begin{array}{l}\text { Subjects } \\
\text { (Nos. in parenthesis) }\end{array}$} & \multicolumn{2}{|c|}{ Red Cell Volumes (ml.|kg.) } \\
\hline & Observed Range & Mean \pm S.E. \\
\hline $\begin{array}{l}\text { Elderly } \subsetneq(27) \\
\text { Elderly }{ }^{*}(10)\end{array}$ & $\begin{array}{l}17.0 \text { to } 30.0 \\
21.6 \text { to } 33.0\end{array}$ & $\begin{array}{l}24 \cdot 26 \pm \mathbf{7 \cdot 4 5} \\
27 \cdot 45 \pm \mathbf{8 \cdot 7 8}\end{array}$ \\
\hline $\begin{array}{l}\text { Young } q(6) \\
\text { Young } \delta(6)\end{array}$ & $\begin{array}{l}20.0 \text { to } 26.0 \\
29.5 \text { to } 32.8\end{array}$ & $\begin{array}{l}23.0 \pm 5.28 \\
30.9 \pm 3.08\end{array}$ \\
\hline $\begin{array}{l}\text { Active elderly }+(8) \\
\text { Inactive elderly } \subsetneq(15)\end{array}$ & $\begin{array}{l}22.0 \text { to } 29.0 \\
17.0 \text { to } 30.0\end{array}$ & $\begin{array}{l}25.40 \pm 5.6 \\
24.45 \pm 5.7\end{array}$ \\
\hline
\end{tabular}

Edwards and Whyte (1960), because of the difficulty in measuring height in kyphotic people. For this reason the range of values observed in most groups is wider than that usually accepted in younger subjects. As an illustration of this point the lowest value in the female control group $(20 \mathrm{ml} . / \mathrm{kg}$.) becomes $23 \mathrm{ml} . / \mathrm{kg}$. when corrected for obesity.

RED CELL VOLUME AND BLOOD VOLUME The results were subjected to statistical analysis and are summarized in Table I. They are expressed below as the mean and standard error in the population represented. The range of observed values in each group is also shown.

The difference between red cell volume in young women (23.0 $\pm 5.28 \mathrm{ml}$. per $\mathrm{kg}$.) and in young men $(30.9 \pm 3.08 \mathrm{ml}$. per $\mathrm{kg}$.) was significant $(\mathrm{P}<0.01)$. No significant difference emerged between the red cell volume in young and elderly women, nor between those of young and elderly men. The difference between red cell volume in elderly women $(24.26 \pm 7.45 \mathrm{ml}$. per $\mathrm{kg}$.) and elderly men $(27.45 \pm$ $8.78 \mathrm{ml}$. per kg.) reached significance at the $P=0.05$ level but not at $\mathbf{P}=0.01$. The blood volumes of the aged subjects also did not differ significantly from those of the controls.

RED CELL SURVIVAL In 11 elderly subjects, the range of the values for $\mathrm{T} \frac{1}{2} \mathrm{Cr}$ was 24.4 to 31.6 days (Table II). These figures do not differ significantly from those of the young controls or from those ob-

TABLE II

\begin{tabular}{|c|c|c|c|}
\hline \multicolumn{4}{|c|}{ RED CELL SURVIVAL $\left(\mathrm{T}_{\frac{1}{2}}{ }^{51} \mathrm{Cr}\right)$ IN DAY } \\
\hline $\begin{array}{l}q \\
q \\
q \\
+ \\
+ \\
0 \\
0 \\
q \\
q \\
q \\
0 \\
0 \\
q \\
+\end{array}$ & $\begin{array}{l}25.7 \\
25.0 \\
29.0 \\
24.4 \\
30.6 \\
27.0 \\
25.0 \\
30.6 \\
29.2 \\
26.0 \\
27.0\end{array}$ & $\begin{array}{l}0 \\
0 \\
0 \\
0 \\
0 \\
0 \\
0 \\
0 \\
0\end{array}$ & $\begin{array}{l}31 \cdot 0 \\
26 \cdot 7 \\
27 \cdot 2 \\
30 \cdot 0 \\
31 \cdot 0 \\
24 \cdot 7\end{array}$ \\
\hline
\end{tabular}

\begin{tabular}{|c|c|c|}
\hline \multicolumn{2}{|c|}{ Blood Volumes (ml.|kg.) } & \multirow{2}{*}{$\begin{array}{l}\text { Significan } \\
\text { Difference }\end{array}$} \\
\hline Observed Range & Mean \pm S.E. & \\
\hline $\begin{array}{l}42.0 \text { to } 81.0 \\
55.4 \text { to } 81.0\end{array}$ & $\begin{array}{l}63 \cdot 13 \pm 18.88 \\
70.5 \pm 18.20\end{array}$ & $0.05>P$ \\
\hline $\begin{array}{l}56.0 \text { to } 72.0 \\
69.0 \text { to } 82.6\end{array}$ & $\begin{array}{l}63.67 \pm 16.10 \\
76.5 \pm 11.55\end{array}$ & $P<0.01$ \\
\hline $\begin{array}{l}58.0 \text { to } 76.0 \\
42.0 \text { to } 81.0\end{array}$ & $\begin{array}{l}67.0 \pm 12.5 \\
63.0 \pm 20.5\end{array}$ & Nil \\
\hline
\end{tabular}

served in young adults by Mollison and Veall (1955) Donohue, Motulsky, Giblett, Eloise, Pirzio-Birol Viranuvatti, and Finch (1955), and Read, Wilsoni? and Gardner (1954).

DISCUSSION

This investigation has shown that, in terms of bod weight, the mean red cell and blood volumes iro elderly men and women are comparable with those in the young. The findings for the red cell volume of $27.45 \mathrm{ml}$. per $\mathrm{kg}$. in men and of $24.24 \mathrm{ml}$. per kg. i women are in agreement with those of Smith (1958) whose figures for men and women over 60 were $28.4 \mathrm{ml}$. per kg. and $22.4 \mathrm{ml}$. per $\mathrm{kg}$. respectivelyo They are also very close to Crawford and de Gruchy's figures of $27.7 \mathrm{ml}$. per kg. for males an $24.4 \mathrm{ml}$. per $\mathrm{kg}$. for females below middle age. Thê difference in red cell volume between males and females becomes less in the elderly (significant a $\mathbf{P}=0.05$ but not at $\mathbf{P}=\mathbf{0 . 0 1}$ ), and this is mirrored $i$ a smaller difference in $\mathrm{Hb}$ levels in the elderly reported by some workers (M.R.C. Special Report, 1945; Naguchi, 1959). Blood volumes were alsô found to differ between the sexes in both young an old subjects, but no such difference existed betwee? the values in the elderly and young members of tho same sex.

It will be seen from Table I that there is a widie range of observed values for red cell and blood volumes in the elderly, and some of the results are outside the limits shown by the controls. It was not possible to account on clinical grounds for the low values found in seven of the subjects. It is thus evident that with body weight as a reference standar $\Phi$ there is a large variation in the individual values of red cell or blood volumes in the elderly.

Other reports have concluded that the red cell an blood volumes are reduced in old age, but it is possible that a mild degree of anaemia was presen in some of the subjects. Sklaroff (1956) found by method using radio-iodinated serum albumin that the plasma and blood volumes in residents of an ols 
people's home were lower than in a young population. Although his cases were probably representative of geriatric subjects, he did not exclude the possibility that they might have been mildly anaemic. Reeve et al. (1959), using a radio-chromium technique, showed that the red cell and blood volumes of elderly men were lower than those of the control population studied by Crawford and de Gruchy (1958). These authors do not state the Hb concentrations in their subjects, and agree that some of their patients may have been undernourished.

A similar criticism may be levelled against largescale surveys of $\mathrm{Hb}$ concentration in the population. In a study of $\mathrm{Hb}$ values in New South Wales, Walsh, Arnold, Lancaster, Coote, and Cotter (1953) found that the average $\mathrm{Hb}$ concentration fell in people over the age of 60 . The subjects were longstay inhabitants of state homes, and the possibility of some undernutrition could not be excluded. The $\mathrm{Hb}$ concentration in old people could also be affected by chronic infection, iron deficiency, and renal insufficiency, although these are not inevitable consequences of old age. Therefore, patients with these conditions were not included in our study. It might be argued, however, that even if the haematocrit were over $40 \%$, the red cell volume would be reduced if the blood volume were small. Direct estimation of the red cell volume in this series of old people has not shown this to be so. Discrepancies in the values for red cell volume in some of the published series could be partly explained by the use of different techniques. It has been shown that direct measurement of red cell volume by ${ }^{51} \mathrm{Cr}$ is less variable than that of plasma volume by Evans blue (Remington and Baker, 1961).

Many of the hospital patients in this series were immobilized or capable only of minimal activity because of their disability. The red cell and blood volumes of the eight most active people and the 15 most inactive patients were compared but were not found to differ (Table I). Taylor, Erickson, Henschel, and Keys (1945) observed in a small group of healthy volunteers that absolute bed rest for three weeks resulted in a reduction of blood volume, but not of red cell volume. This work is not comparable with that reported here, as observations were made on each subject before and after immobilization.

It is therefore concluded that the red cell and blood volumes in a normal elderly population are comparable with those in the young, although the difference between the sexes in these values is less marked. It is also concluded that there is no change in the life span of red cells with age, if the survival is measured within the donor's own circulation.

We are very grateful to Dr. J. Kaminski, Dr. H. I. Coombs, and Dr. W. K. Badgett, whose patients provided much of the material for the investigation. We would also like to thank Dr. J. G. Selwyn, Dr. M. Lubran, and Dr. S. M. Lewis for their help and advice.

\section{REFERENCES}

Casassa, P. M., Cerrato, G., and Turco, G. L. (1957). G. Geront. (Firenze), 5, 760.

Chaplin, H. Jr., and Mollison, P. L. (1952). Blood, 7, 1227.

Crawford, H., and de Gruchy, G. C. (1958). Med. J. Aust., 1, 657.

Donohue, D. M., Motulsky, A. G., Giblett, Eloise R., PirzioBiroli, G., Viranuvatti, V., and Finch, C. A. (1955). Brit. J. Haemat., 1, 249.

Edwards, K. D. G., and Whyte, H. M. (1960). Clin. Sci., 19, 399.

Medical Research Council Committee on Haemoglobin Surveys (1945). Special Report Series No. 252. H.M. Stationery Office, London.

Mollison, P. L., and Veall, N. (1955). Brit. J. Haemat., 1, 62.

Naguchi, K. (1959). J. Nagoya med. Ass., 77, 8.

Read, R. C., Wilson, G. W., and Gardner, F. H. (1954). Amer. J. med. Sci., 288, 40.

Reeve, T. S., Oddie, T. H., Bowman, S., and Rundle, F. F. (1959). Aust. N.Z. J. Surg., 28, 221.

Remington, J. W., and Baker, C. H. (1961). Circulat. Res., 9, 60.

Sklaroff, D. M. (1956). Amer. J. Roentgenol., 75, 1082.

Smith, R. H. (1958). Anesthesiology, 19, 752.

Takaku, F. (1959). Acta haemat. jap., 22, 464.

Taylor, H. L., Erickson, L., Henschel, A., and Keys, A. (1945). Amer. J. Physiol., 144, 227.

Walsh, R. J., Arnold, B. J., Lancaster, H. O., Coote, M. A., and Cotter, H. (1953). A Study of Haemoglobin Values in New South Wales. Special Report Ser. No. 5. National Health and Medical Research Council, Canberra. 